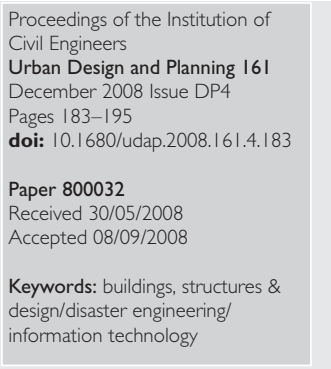

Feniosky Peña-Mora
Professor of Construction
Management and
Information Technology,
University of Illinois at
Urbana-Champaign,
Illinois, US
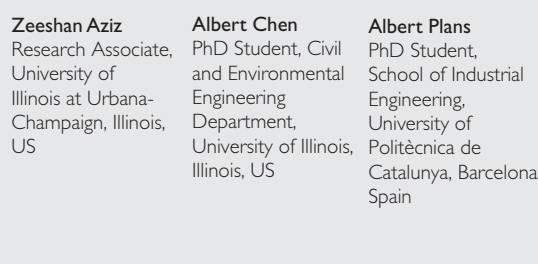

Stuart Foltz Research Civil Engineer, Army Corps of Engineers, Construction Engineering Research Laboratory, Engineering Research and Development Centre (ERDC-CERL). Champaign, Illinois, US

\title{
Building assessment during disaster response and recovery
}

\author{
F. Peña-Mora MS, PhD, Z. Aziz MS, PhD, A. Y. Chen MS, A. Plans MS and S. Foltz MS
}

During disaster response and recovery operations, civil engineers can be assigned a multitude of tasks including triage of building search priorities, identification and evaluation of structural hazards, as well as the development of appropriate structural hazard mitigation techniques and monitoring of hazards, while coordinating and reporting this information to the incident command centre (ICC). This paper reviews the role of civil engineers in disaster response with a focus on existing building assessment and marking systems and highlights various limitations of existing approaches. A mobile information technology (IT)-based collaborative framework is discussed to facilitate a coordinated disaster response and recovery operation. It enables engineers to assess building damage better and to make this information available to personnel more quickly and easily within the disaster area and thereby improve disaster response. The deployed architecture is composed of various components including radio frequency identification (RFID)-based structural assessment, a field engineer's mobility and information support platform and geographic information systems (GIS)-based resource optimisation. Deployed infrastructure enables the on-site and on-demand information provisioning, data processing and computational support required by engineers in the aftermath of a disaster.

\section{INTRODUCTION}

Modern cities are complex and rely on inter-dependent systems including a mix of utilities, transportation and telecommunication infrastructure, commercial and residential building; this makes them extremely vulnerable. The critical role played by civil engineers to promote urban resilience has long been recognised. ${ }^{1-3}$ Technically sound and timely decisions by engineers may mean the difference between life and death in a disaster response operation. ${ }^{4}$ A significant role for civil engineers to promote urban resilience through application of engineering expertise including structural, construction, geotechnical, environmental, hydraulic and transportation knowledge has previously been emphasised. ${ }^{3}$ Table 1 summarises key facets of the role of civil engineers during disaster response operations to attain high levels of disaster resilience.

A well-planned, prompt and accurate building damage assessment and reporting procedure is vital to ensure effective disaster response and recovery and in restoring/improving pre-disaster built environment conditions. The structure triage, assessment and marking system is designed to help identify, select and prioritise building(s) with the highest probability of success with respect to finding and rescuing live victims. ${ }^{5}$ The system assists engineers in evaluating several buildings to determine which structures will receive operational priority. The priority is based on a score, which is influenced by the building's occupancy, collapse mechanism, time to get to victims, prior intelligence, resources available and structural condition. Buildings with higher scores receive attention first, to improve the search and rescue performance. ${ }^{6}$

The current research paper presents the work done related to the building assessment component of the "collaboration for preparedness, response and recovery' (CP2R) project, ${ }^{7}$ which has focused on improving the collaboration among the key actors that should be involved in preparedness against disaster (i.e. beforehand), response and recovery to disaster (i.e. afterwards) in reacting to extreme events (XEs) involving critical physical infrastructure. The rest of the paper is organised as follows. Section 2 reviews most commonly used post-disaster building assessment marking systems used in the USA, whereas section 3 discusses the state of the art in building assessment procedures and new technologies used to support it. Section 4 analyses limitations of existing post-disaster building assessment approaches. Section 5 discusses a mobile information technology (IT) system architecture and implementation to address various limitations. Field trials undertaken to validate the system are discussed in Section 6 and conclusions are drawn about the possible future impact of this work in Section 7.

\section{REVIEW OF POST-DISASTER BUILDING ASSESSMENT AND MARKING SYSTEMS}

A key objective of post-disaster building assessment and marking systems (BAMS) is to communicate buildings' stability and suitability information to all concerned personnel involved in disaster response and recovery for performing rescue, recovery or crime investigation activities inside the building. BAMS ensure that rescue teams are aware of hazardous areas in damaged buildings. Thus, it is important that information related to building identification, conditions, hazards and victim status be marked in a standardised fashion. In an urban environment building marks also serve as a communication channel between engineers, fire-fighters (local and regional level) and task forces (federal level) and often help to keep 
- Identify structural hazards that threaten the safety of rescue personnel and propose safest routes to reach survivors

- Design structural hazard mitigation measures, including shoring and bracing for unstable structures

- Identify alternatives for mitigation of structural hazards to minimise risks to rescue personnel

- Monitor structural stability under changing conditions

- Identify dangers posed by loose debris and recommend priority of removal

- Provide orientation and marking within a structure

- Assist with safe placement and operation of heavy equipment

- Triage collapse area for search operations

- Assessment of structures adjacent to immediate disaster area

- Identify likely void locations to assist locating victims
- Initialise structure triage and assessment

- Coordination and exchange of all other pertinent information such as

- structure assessments

- mitigation plans, logs and priorities

- monitoring plans and logs

- prioritise, coordinate and provide design support for hazard mitigation

- Help manage and coordinate the work of contractors

Table I. Role of civil engineers in disaster response

track of their location. Different BAMS are often deployed in disaster response operations and are often used to pursue different goals. They have been used in almost all major disasters in the US in recent years. The most commonly used BAMS are discussed below.

\section{I. National urban search and rescue response system}

The US Federal Emergency Management Agency (Fema) (US\&R) response system ${ }^{6}$ is the national standard system for identifying, evaluating and marking buildings. It was established to ensure differentiation of structures within a geographic area and to communicate the structural condition and status of USER operations within a structure. The marking is divided into four categories for identification, structure/hazards evaluation, victim location and search assessment marking. ${ }^{6}$ Building marks are made on structures with international orange paint, and placed on the building surface or a nearby flat surface (Fig. 1). This specific colour is actually assigned to USER building marks because of its clear visibility, showing key assessment information to all the personnel involved in operations.

\subsection{International search and rescue response system} The international search and rescue response system (INSAR) ${ }^{9}$ was created to assist international search and rescue (SAR) teams. It includes a complete framework to develop the SAR activities, including a building marking system to assess buildings in a disaster event, which seeks to standardise the way to post the information to ensure uniformity and clarity. Information is posted with fluorescent colour (Fig. 2) to identify and mark structures permanently. The INSAR system is divided into various categories including assigned areas or work site, structure assessment, general hazards marking, facility/vehicle markings, potential void identification, team/functional markings, symbols and signalling.
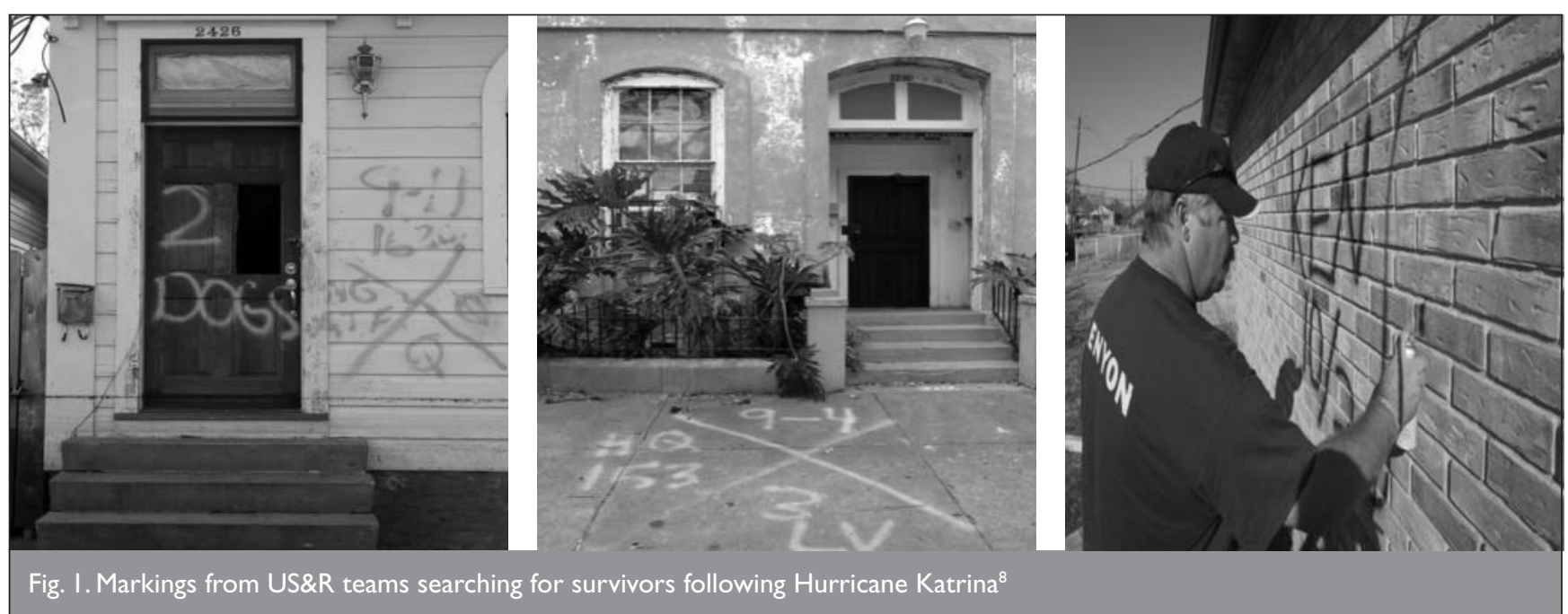

Fig. I. Markings from US\&R teams searching for survivors following Hurricane Katrina ${ }^{\varepsilon}$ 


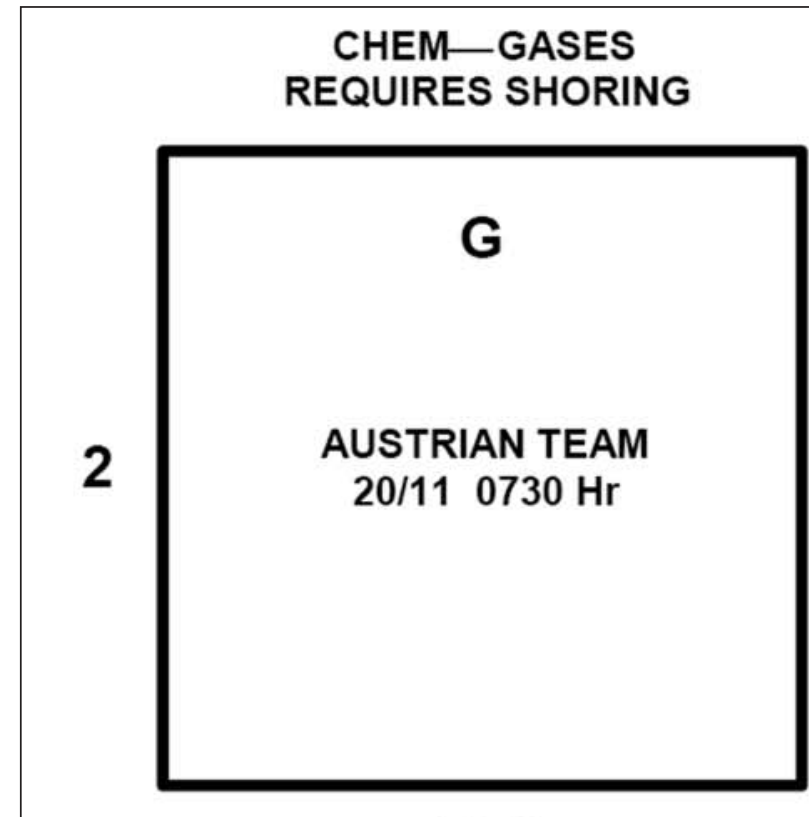

$12 ?$

(a)

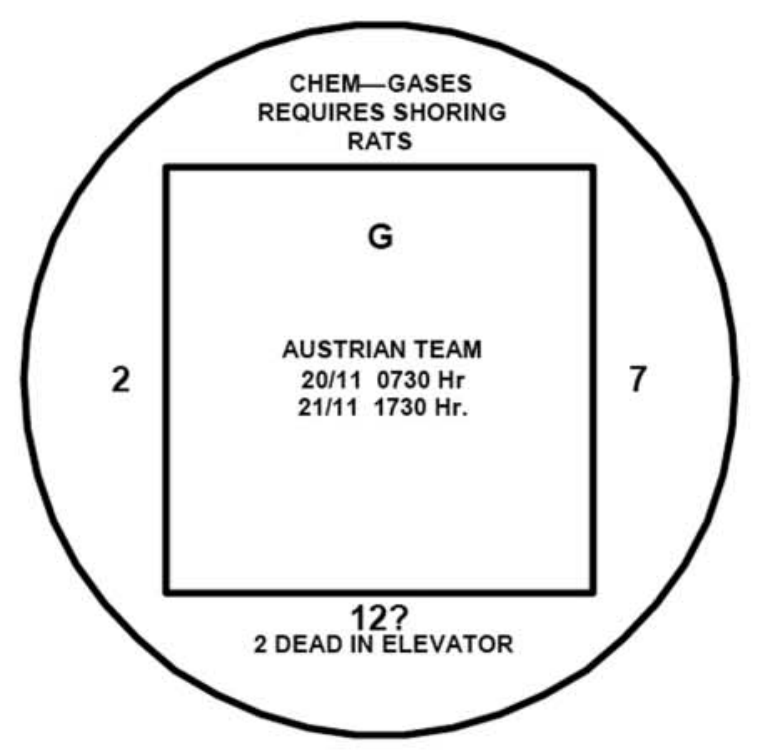

(b)

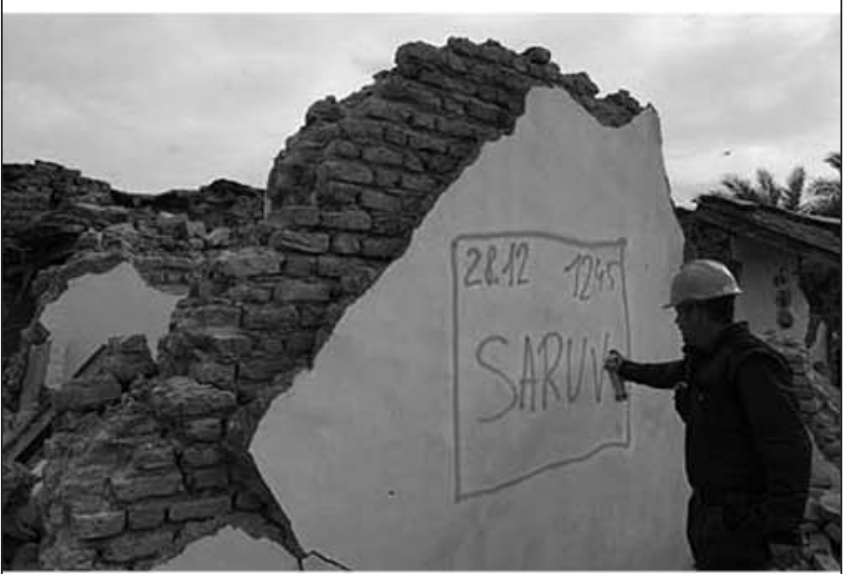

(c)

Fig. 2. (a) INSAR structure assessment. Sample marking 'Work in progress' and (b) a sample marking for a 'Work complete' status ${ }^{10}$ with (c) photograph"

\subsection{Applied Technology Council' ${ }^{12}$}

The Applied Technology Council (ATC) has developed different manuals detailing procedures for post-disaster building assessment. Their use is recommended for the following disaster types: earthquakes, windstorms, hurricanes, snow storms, fires, floods, tsunamis, blasts, crashes and terrorist incidents. ${ }^{2}$ ATC has various field manuals which give advice on evaluating structural, geotechnical and non-structural risks, and on estimating the impact to safety of different types of building damage. The focus of the manuals is on buildings, and not on other engineering facilities such as bridges or pipelines. Unlike USER and INSAR, the marking system is for recovery, not rescue. The ATC-20 procedures gained a great acceptance owing to their deployment after the $9 / 11$ attacks, and now they have become a de facto standard for rapid structures inspection of buildings and other structures in the US. ${ }^{2}$ ATC procedure defines three levels of evaluation, namely, rapid, detailed and engineering evaluation developed for different personnel (Fig. 3).

To specify clearly the extent of a building damage, the ATC procedures include a standard method to identify buildings through three levels of colour-coded placards. Table 2 highlights the main characteristics for each class.

To facilitate the collection and management of data, ATC and Buidfolio Incorporated developed the ATC-20 $\mathrm{i}^{14}$ personal digital assistant (PDA) application. This enables engineers to document inspection results using electronic input screens that duplicate the ATC-20 rapid and detailed evaluation forms and to upload the data by way of wireless technology, or the internet, to a server where the data can be reviewed, summarised and managed by the user and by building departments.

\section{APPLICATION OF TECHNOLOGIES TO FACILITATE BUILDING ASSESSMENT}

In recent years various research groups and commercial organisations have focused on application of emerging technologies to facilitate building assessment. Various approaches of macro-level building damage assessment using satellite imagery and remote sensing are also proposed. ${ }^{15,16}$ Sextos et al. ${ }^{17}$ presented a computer-aided strategy for the rapid visual inspection of buildings and prioritisation of strengthening and remedial actions using computer-aided pre/ post-earthquake buildings assessment involving database compilation, geographic information system (GIS) visualisation and mobile data transmission. Earthdata International ${ }^{18}$ has used mapping techniques (based on sensorial gathering of data) in buildings for several purposes. As part of air-borne rapid imaging for emergency support (aries) project, Earthdata ${ }^{18}$ is focusing on gathering and processing multi-sensor geospatial information, integrating existing tabular data and producing high-quality information in a minimum of time between data collection and delivery of products to first responders. Researchers have also highlighted the importance of threedimensional laser scanning tools to assess building damage in the response phase of an extreme event. ${ }^{19}$ Behzadan et al. ${ }^{20}$ discussed application of ubiquitous hybrid location tracking technology that could automatically provide engineers and first responders with accurate, prioritised contextual information by retrieving previously stored building information and superimposing that information on a real building using augmented reality to evaluate building damage, 


\begin{tabular}{|c|c|c|}
\hline \multirow{2}{*}{$\begin{array}{l}\text { ATC-20 } \\
\text { Technique }\end{array}$} & \multicolumn{2}{|c|}{ Building Evaluation Techniques } \\
\hline & $\begin{array}{l}\text { Required } \\
\text { Personnel }\end{array}$ & Goal \\
\hline $\begin{array}{l}\text { Rapid } \\
\text { Evaluation }\end{array}$ & $\begin{array}{l}\text { Building } \\
\text { inspectors: } \\
\text { Civil/Structural } \\
\text { engineers; } \\
\text { Architects }\end{array}$ & $\begin{array}{l}\text { Rapid assessment of } \\
\text { safety. Used to quickly } \\
\text { post obviously unsafe and } \\
\text { apparently safe structures, } \\
\text { and to identify buildings } \\
\text { requiring Detailed } \\
\text { Evaluation }\end{array}$ \\
\hline $\begin{array}{l}\text { Detailed } \\
\text { Evaluation }\end{array}$ & $\begin{array}{l}\text { Structural } \\
\text { engineers* }\end{array}$ & $\begin{array}{l}\text { Careful visual evaluation } \\
\text { of damaged buildings and } \\
\text { questionable situations. } \\
\text { Used to identify buildings } \\
\text { requiring an Engineering } \\
\text { Evaluation }\end{array}$ \\
\hline $\begin{array}{l}\text { Engineering } \\
\text { Evaluation }\end{array}$ & $\begin{array}{l}\text { Structural } \\
\text { engineering } \\
\text { consultant }\end{array}$ & $\begin{array}{l}\text { Detailed engineering } \\
\text { investigation of damaged } \\
\text { buildings, involving use of } \\
\text { construction drawings, } \\
\text { damage data, and new } \\
\text { structural calculations. }\end{array}$ \\
\hline \multicolumn{3}{|c|}{$\begin{array}{l}\text { - Geotechnical specialists required for assessment of } \\
\text { geotechnical hazards }\end{array}$} \\
\hline
\end{tabular}

(a)

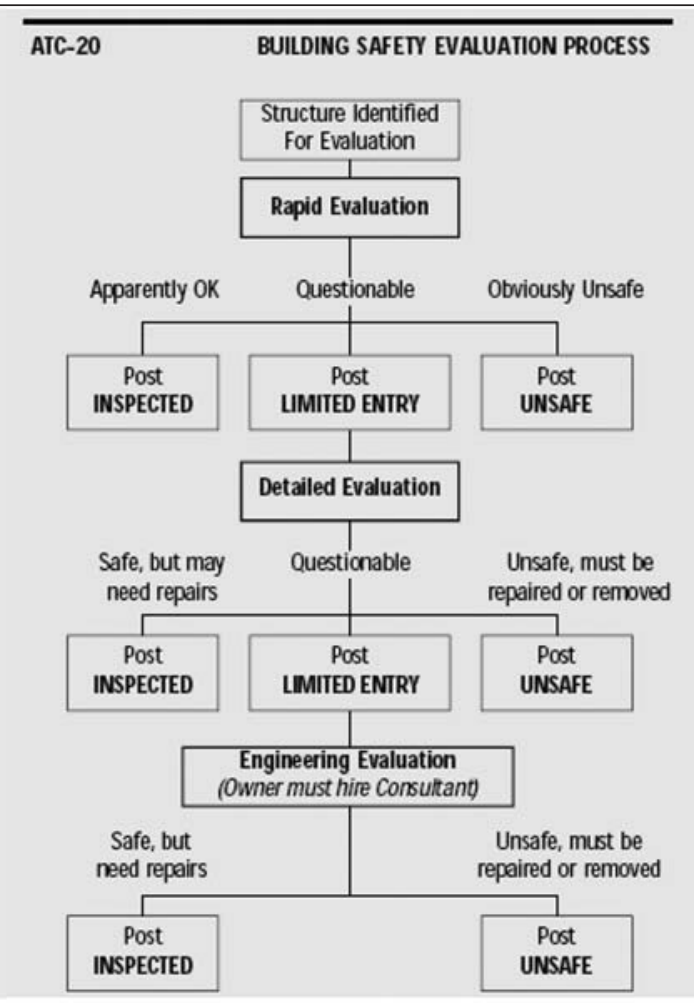

(b)

Fig. 3. Flowchart illustrating (a) building safety evaluation process and (b) building evaluation techniques'2

\begin{tabular}{|lll|}
\hline Colour & Posting classification & \multicolumn{1}{c|}{ Description } \\
\hline Green & $\begin{array}{l}\text { Inspected } \\
\text { Yellow }\end{array}$ & $\begin{array}{l}\text { Limited entry/ } \\
\text { significantly decreased. No restriction on use or occupancy }\end{array}$ \\
restricted use & $\begin{array}{l}\text { Dangerous condition believed to exist. Entry by owner permitted only for emergency purposes and } \\
\text { only at own risk. No usage on a continuous basis. Entry by public not permitted. Possible major } \\
\text { aftershock hazard }\end{array}$ \\
Red & Unsafe & $\begin{array}{l}\text { Extreme hazard, may collapse. Imminent danger of collapse from an aftershock. Unsafe for occupancy } \\
\text { or entry, except by authorities (entry controlled by jurisdiction) }\end{array}$ \\
\hline Table 2. ATC-20 Building Safety Evaluation Classifications (adapted from SEAoNY13)
\end{tabular}

structural integrity and safety. Digital measurements are also used to complement on-site building observation. For instance, the Exponent wireless building monitoring system ${ }^{21}$ allows, through its sensors, a real-time monitoring of the building's tilt angle. The sensors are attached to columns and/or beams, and once they are initialised to the benchmark position, every $5 \mathrm{~s}$ an updated position is broadcast to the receivers. Receivers send data gathered to the PDA or laptop by way of a Bluetooth component. In the case where the original conditions change (e.g. slight movement in buildings), the system automatically launches an alarm state.

While the aforementioned initiatives have concentrated on using individual technology components to support building assessment during disaster response, there is a need for an integrated framework and a holistic approach to support building assessment operations as part of disaster response.

\section{LIMITATIONS OF EXISTING POST-DISASTER BUILDING ASSESSMENT APPROACHES}

The various BAMS discussed in section 2 differ in terms of their scope and focus, and very often different marking systems are used within the same disaster zone at the same time by different agencies involved in disaster response and recovery efforts. Frequently, different BAMS are used at local, regional and national levels. The presence of different building marking systems introduces complexity in their understanding. Rescuerecovery teams have to deal with a large number of symbols. Different organisations, with different marking systems, means duplication of work. Literature review and detailed interviews with experienced personnel from the Illinois Fire Service Institute (IFSI) and the US Army Corps of Engineers, who have been involved in disaster response for the 9/11 terrorist attacks, Hurricane Katrina and numerous other disasters, have provided some insight into various obstacles to effective disaster 
response (Table 3). The approach taken to address these obstacles is also briefly discussed and further explained in section 4. Table 4 maps identified user requirements with $\mathrm{CP} 2 \mathrm{R}$ component technologies.

\section{SYSTEM ARCHITECTURE AND IMPLEMENTATION}

Figure 4 describes the system architecture, which is composed of various components including radio frequency identification (RFID)-based structural assessment, a field engineer's mobility and information support platform and a GIS-based resource optimisation component. The system provides the required computing infrastructure such as onboard processing, database accessibility and storage, software access and immediate communication tools to overcome past limitations. Implementation of the system components is discussed in the following subsections.

\section{I. RFID-based building assessment}

Radio frequency identification technology is used as the basis of a structural assessment system (Fig. 5). Supported by

\begin{tabular}{|c|c|c|}
\hline Identified requirement & Brief description & Current authors' approach \\
\hline \multirow[t]{2}{*}{$\begin{array}{l}\text { Communication and } \\
\text { collaboration support }\end{array}$} & $\begin{array}{l}\text { - 'No communication, miscommunication and } \\
\text { misleading information' to emergency } \\
\text { responders } \\
\text { - Difficulties in knowledge sharing } \\
23\end{array}$ & $\begin{array}{l}\text { Provision of real-time communication support } \\
\text { infrastructure for first responders }\end{array}$ \\
\hline & $\begin{array}{l}\text { 'Inability to access information and the } \\
\text { lack of standardization, collaboration, } \\
\text { coordination, and communication'24 }\end{array}$ & $\begin{array}{l}\text { Real-time information provision using mobile IT } \\
\text { and wearable computers for field engineers }\end{array}$ \\
\hline $\begin{array}{l}\text { Provision of real-time data to } \\
\text { field personnel }\end{array}$ & $\begin{array}{l}\text { 'First responders' need for information } \\
\text { access and sharing are not well supported, } \\
\text { and are often disconnected from both the } \\
\text { information systems and databases central to } \\
\text { effective homeland security'25 }\end{array}$ & $\begin{array}{l}\text { Real-time information provisioning by way of } \\
\text { support devices embedded in personal mobility } \\
\text { platform }\end{array}$ \\
\hline $\begin{array}{l}\text { Provision of real-time data to } \\
\text { incident command post }\end{array}$ & $\begin{array}{l}\text { 'Problems or delays in data collection, access, } \\
\text { usage and dissemination has negative impacts } \\
\text { on the quality of decision making and hence } \\
\text { the quality of disaster response'26 }\end{array}$ & $\begin{array}{l}\text { Provision of real-time video/audio/building data } \\
\text { from disaster site to decision makers }\end{array}$ \\
\hline $\begin{array}{l}\text { Unified approach to data } \\
\text { handling }\end{array}$ & $\begin{array}{l}\text { - 'Current practices of evaluating damage to } \\
\text { buildings after catastrophic events are labour } \\
\text { intensive, time consuming and error prone' }\end{array}$ & Application of a unified approach to data handling \\
\hline Visual data capture & $\begin{array}{l}\text { 'Although different types of disasters call for } \\
\text { different types of response, most situations } \\
\text { can be improved by having visual images and } \\
\text { other remotely sensed data available'28 }\end{array}$ & $\begin{array}{l}\text { Capturing visual data from disaster site including } \\
\text { video and still images }\end{array}$ \\
\hline $\begin{array}{l}\text { On-site building assessment } \\
\text { marking }\end{array}$ & $\begin{array}{l}\text { Building marks not being visible because of } \\
\text { re-marking/smoke/debris on site and are } \\
\text { updated at ICC after } 8-12 \mathrm{~h} \text { through its } \\
\text { established work cycles }\end{array}$ & $\begin{array}{l}\text { Reduced reliance on visual building markings } \\
\text { through use of a radio-frequency-based approach } \\
\text { for on-site data recording and capture. }\end{array}$ \\
\hline $\begin{array}{l}\text { Access to building design } \\
\text { documents }\end{array}$ & $\begin{array}{l}\text { 'The architect and structural engineering } \\
\text { firms used for the design of the buildings } \\
\text { should be identified, as well as the actual } \\
\text { architect and engineer of record. This } \\
\text { information will prove very useful for finding } \\
\text { drawings, assigning assessment teams and } \\
\text { obtaining other information during a } \\
\text { disaster'4 }\end{array}$ & $\begin{array}{l}\text { Use of a black box to store relevant building } \\
\text { information }\end{array}$ \\
\hline Personal mobility support & $\begin{array}{l}\text { ' } . \text {. the structural engineering teams had to } \\
\text { walk at least two miles before they even } \\
\text { began their shift' }\end{array}$ & $\begin{array}{l}\text { Need for a personal mobility support for field } \\
\text { engineers to save time and conserve energy }\end{array}$ \\
\hline Resource allocation issues & $\begin{array}{l}\text { 'Appropriate resource allocation has to be } \\
\text { planned to cover critical infrastructures for } \\
\text { the society'4 }\end{array}$ & Application of GIS technology to manage resources \\
\hline Multiple connectivity options & $\begin{array}{l}\text { Existing terrestrial links can easily saturate } \\
\text { and collapse at time of disasters. For } \\
\text { instance, after } 9 / 1 \mathrm{I} \text { attacks, cellular phones } \\
\text { did not work because of the destruction of } \\
\text { antennae systems }{ }^{4}\end{array}$ & $\begin{array}{l}\text { Support for information sharing among ad hoc } \\
\text { dynamic and informal groups of participants } \\
\text { working collaboratively in a disaster site using both } \\
\text { cellular and peer-to-peer connectivity }\end{array}$ \\
\hline
\end{tabular}




\begin{tabular}{|c|c|c|c|c|c|c|c|c|c|c|}
\hline \multirow{2}{*}{$\begin{array}{l}\text { Identified user } \\
\text { requirements }\end{array}$} & \multicolumn{10}{|c|}{ CP2R component technologies } \\
\hline & RFID & GIS & $\begin{array}{l}\text { Building } \\
\text { black box }\end{array}$ & $\begin{array}{l}\text { Mobility } \\
\text { platform }\end{array}$ & $\begin{array}{l}\text { Photo } \\
\text { capture }\end{array}$ & $\begin{array}{l}\text { Video } \\
\text { capture }\end{array}$ & GPS & $\begin{array}{c}\text { Command } \\
\text { post }\end{array}$ & $\begin{array}{l}\text { Ad hoc } \\
\text { networks }\end{array}$ & $\begin{array}{c}3 G \\
\text { connectivity }\end{array}$ \\
\hline $\begin{array}{l}\text { Communication } \\
\text { and collaboration } \\
\text { support }\end{array}$ & Moderate & Moderate & Moderate & & Strong & Strong & Weak & Strong & Strong & Strong \\
\hline $\begin{array}{l}\text { On-site data } \\
\text { capture }\end{array}$ & Strong & & Strong & Weak & Strong & Strong & Moderate & & Moderate & Moderate \\
\hline $\begin{array}{l}\text { Visual data } \\
\text { capture }\end{array}$ & & & & Moderate & Strong & Strong & & & Moderate & Moderate \\
\hline $\begin{array}{l}\text { Real-time data } \\
\text { for field } \\
\text { engineers }\end{array}$ & Moderate & & & & & & & & Strong & Strong \\
\hline $\begin{array}{l}\text { Real-time data to } \\
\text { command post }\end{array}$ & Strong & Moderate & Strong & Moderate & Strong & Strong & Moderate & Strong & Strong & Strong \\
\hline $\begin{array}{l}\text { On-site building } \\
\text { assessment } \\
\text { record }\end{array}$ & Strong & & Strong & & & & Moderate & & Weak & Weak \\
\hline $\begin{array}{l}\text { Issues with } \\
\text { visibility of } \\
\text { building marks }\end{array}$ & Strong & & & & & & & & Weak & \\
\hline $\begin{array}{l}\text { Access to } \\
\text { building design } \\
\text { documents }\end{array}$ & Strong & & Strong & & & & & & Moderate & Moderate \\
\hline $\begin{array}{l}\text { Personal mobility } \\
\text { support }\end{array}$ & & & & Strong & & & & & & \\
\hline $\begin{array}{l}\text { Resource } \\
\text { allocation/route } \\
\text { determination }\end{array}$ & & Strong & & & Moderate & Moderate & Moderate & Moderate & Moderate & Moderate \\
\hline $\begin{array}{l}\text { Multiple } \\
\text { connectivity } \\
\text { options }\end{array}$ & Moderate & & & & & & & & Strong & Strong \\
\hline $\begin{array}{l}\text { Location tracking } \\
\text { support }\end{array}$ & & & & & & & Strong & & & Moderate \\
\hline $\begin{array}{l}\text { Knowledge } \\
\text { sharing }\end{array}$ & Moderate & Strong & Strong & Strong & Weak & Weak & & & Weak & Weak \\
\hline
\end{tabular}

wireless client-to-server and peer-to-peer applications, RFID-enabled mobile devices and tags represent a method for posting, gathering, storing and sharing information related to building assessment in a timely manner, leading to an improved efficiency and effectiveness of the emergency response. ${ }^{7}$ Client application was developed on a pocket-PC platform, while the building assessment module was developed in C\# using Microsoft.NET framework 2.0 and Compact framework 2.0. extensible mark-up language was used for data exchange. On-site building assessment information is stored on RFID tags attached to buildings. Building assessment information is also stored in the virtual domain using a PDA-based electronic map. Information about all the assessed building within the range of a particular ad hoc network will be displayed on the electronic map. The global positioning system (GPS) extension of the software enables automatic updating and visualisation of the field engineer's location as they comb the disaster site to make assessments of the existing disaster situation. Along with the RFID approach, building information hubs (the building equivalent of the 'black box') were developed. ${ }^{29}$ These intelligent units provide dynamic building information through sensors such as temperature, humidity, personnel location and stresses in structural elements. Additionally, the units contain details of building drawings and historical records that can also support the engineering assessments. Special effort is directed towards disaster survivability, communications and redundancy requirements to provide real-time sensed information to remote teams and to integrate these data in structural models for accurate analysis during and after disasters.

\subsection{Personal mobility and information provisioning platform}

During disaster response and recovery operations time is of the essence. 'The elapsed time directly translates into significant economic losses and to circumstances in which humans are exposed to precarious working and living conditions. ${ }^{27}$ Thus, there is a need to employ innovative solutions to increase access of critical responders to chaotic, hazardous and hostile environments. A mobility platform is used to enable engineers to undertake initial damage reconnaissance and building 

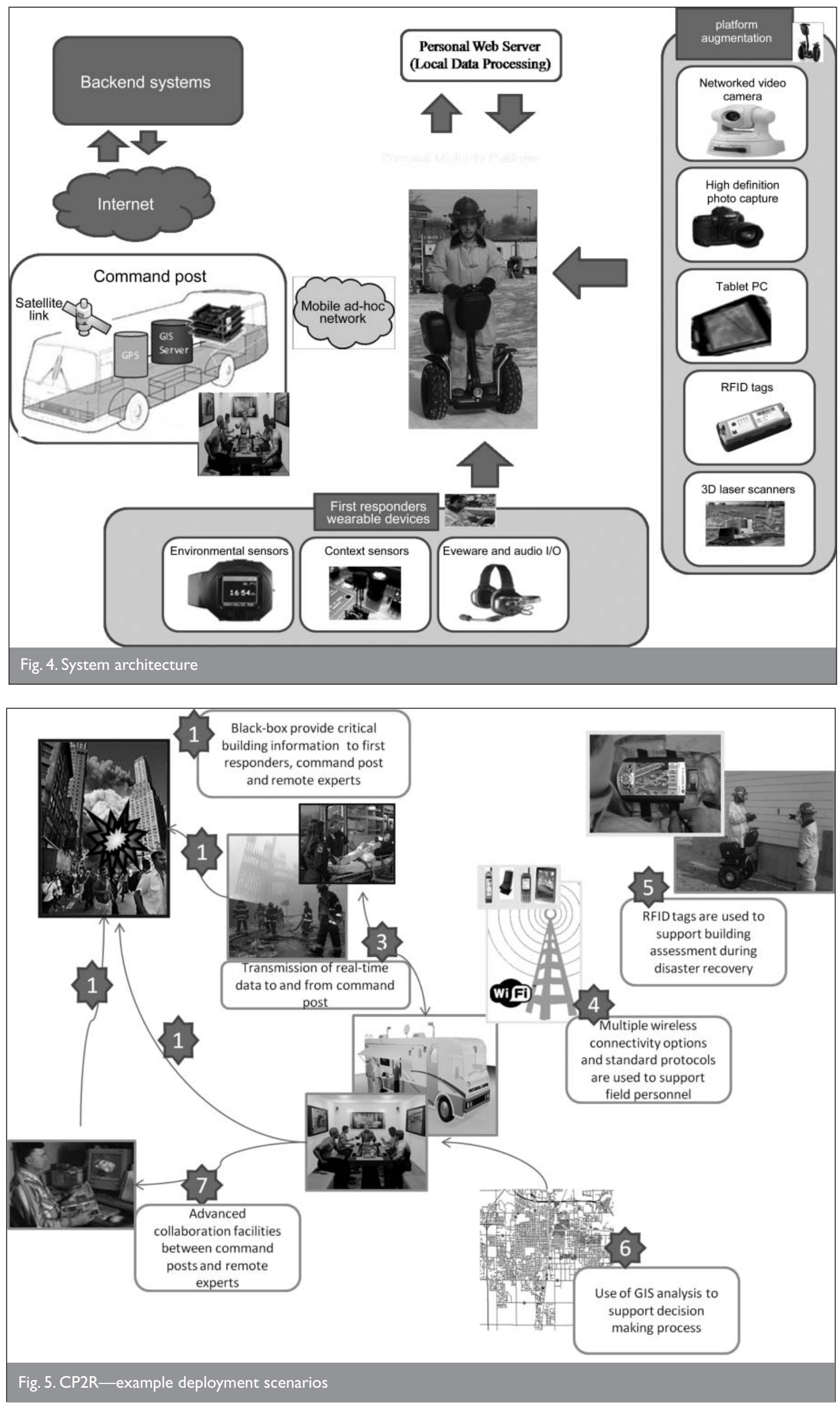
assessment in the shortest possible time and in difficult terrain. Segway is a commercially available self-balancing two-wheeled personal mobility device which is able to balance a person standing on its platform while the engine is kept in motion. It has a speed of up to $22 \mathrm{~km} / \mathrm{h}$. The mobility platform is currently being enhanced to host different computational devices and software applications with data capture and analysis capabilities using the enhanced wireless transmission capabilities built up on the platform. Emergency responders will access specific sets of information through their wearable computers and a tablet-PC affixed to the mobility platform.

\subsection{GIS-based resource optimisation portal}

A GIS-based application supported by decision-making algorithms was developed to prioritise disaster response efforts including routing of first responders and engineers, relief supplies and to support decision making related to search and rescue efforts. Using a standard web browser, decision makers can access field data. The building assessment system externally links to a GIS resource management system to request resources to support search and rescue operations. Within the GIS resource management system (Fig. 6), two major system components are implemented. First, the emergency resource repository portal (E2RP) is a web-based geo-database service. It provides access to resource information for on-site and off-site decision makers. Second, an automated resource management system (ARMS) provides an automated route-finding service for resource allocation operations. Although the two systems could be accessed through the internet in normal conditions, there is a high possibility that infrastructure network communication problems could occur during disaster scenarios. The two systems are assumed to be deployed in the field in a mobile incident command post. On-site decision makers and first responder teams will access the two systems through the ad hoc network established by the CP2R collaboration framework through hypertext transfer protocol (HTTP) and transmission control protocol/internet protocol (TCP/IP) networking.

\subsection{Integration of system components}

The RFID-based building assessment system is deployed along with the tablet PC affixed to the mobility platform. As a result, first responders have access to the RFID-based building assessment system while undertaking initial damage reconnaissance and building assessment on the mobility platform. In addition, the GIS-based resource optimisation portal, deployed on the mobile command centre, is accessible through the ad hoc network established by the CP2R collaboration framework. ${ }^{7}$ Through the ad hoc network, the RFID-based building assessment system interfaces with the GIS-based resource optimisation portal to request critical resource for further response and recovery operations based on the building evaluation using TCP/IP networking protocol. As a result, the system serves as a high-mobility platform with multifunctional services.

\section{SYSTEM EVALUATION}

Field trials of the system were conducted at the IFSI training arena in parallel with a rescue and hazardous material exercise conducted by the Illinois Army National Guard. To test system performance in a realistic setting, the building assessment simulated six building units tested at the World Trade Center (WTC) after the 11 September 2001 attacks. Fig. 7(a) shows a map of the buildings assessed at WTC and Fig. 7(b) illustrates the buildings at the IFSI training area that were replicated for the simulation exercise. These buildings include a six-storey building (labelled 1 in Fig. 7, numbers also correspond to those in Fig. 8), a two-storey building (labelled 2), a one-storey building (labelled 3), light-weight and heavy-weight collapsed

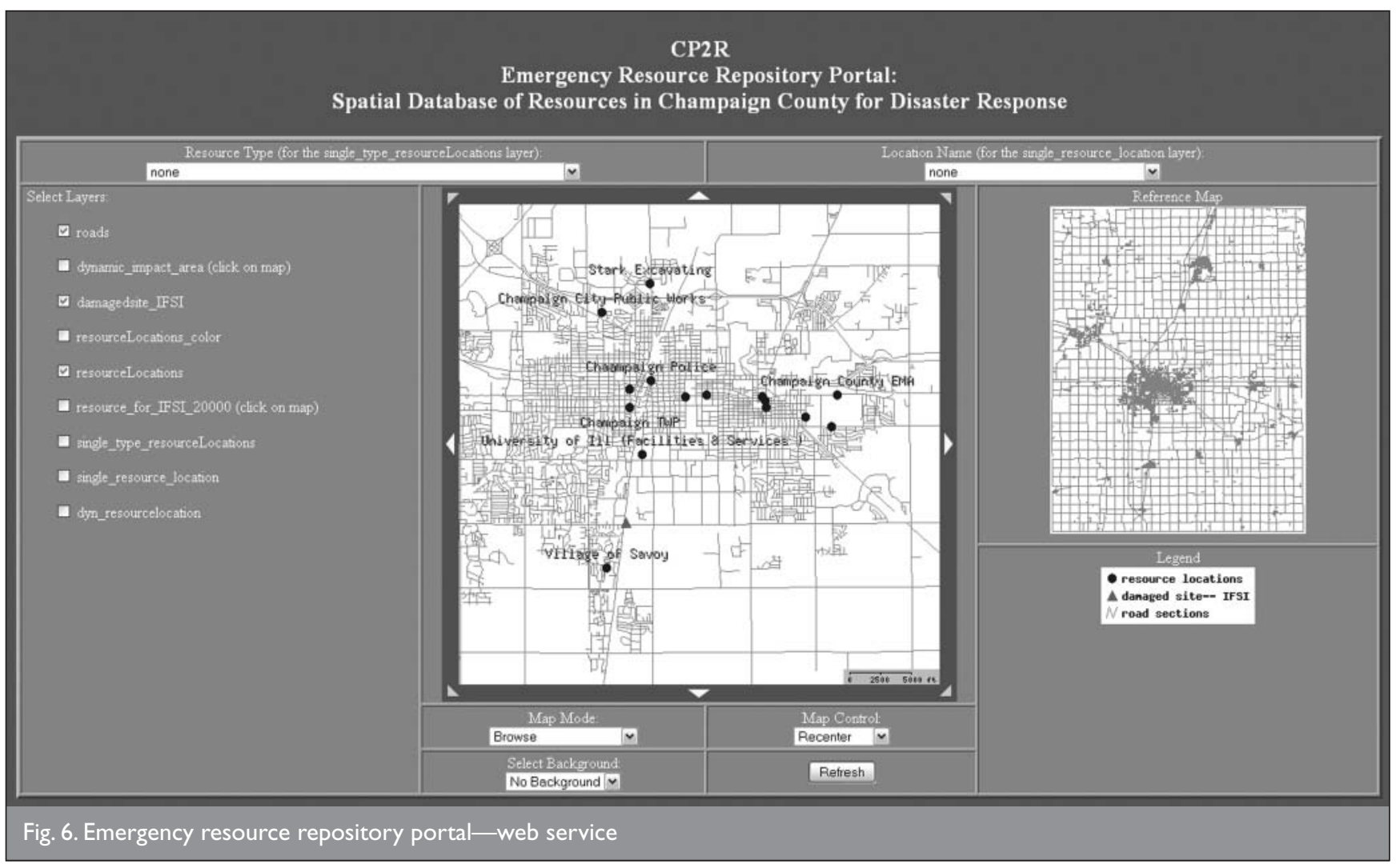




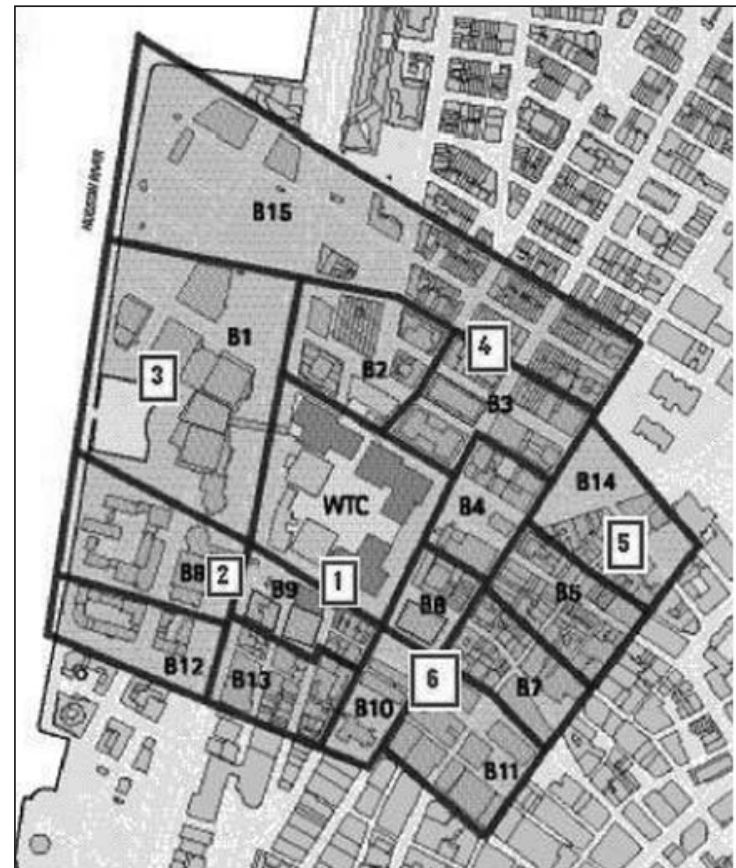

(a)

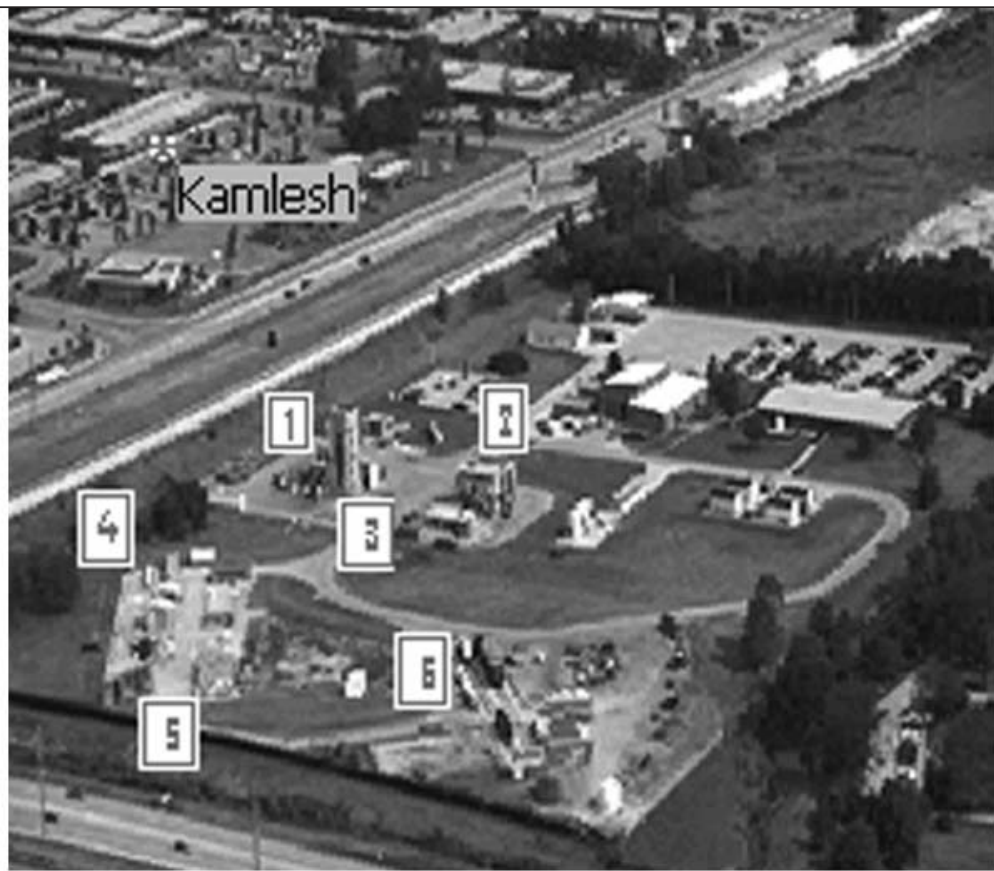

(b)

Fig. 7. (a) WTC map with ATC-20 rapid evaluation representation ${ }^{13}$ and (b) simulated buildings at IFSI

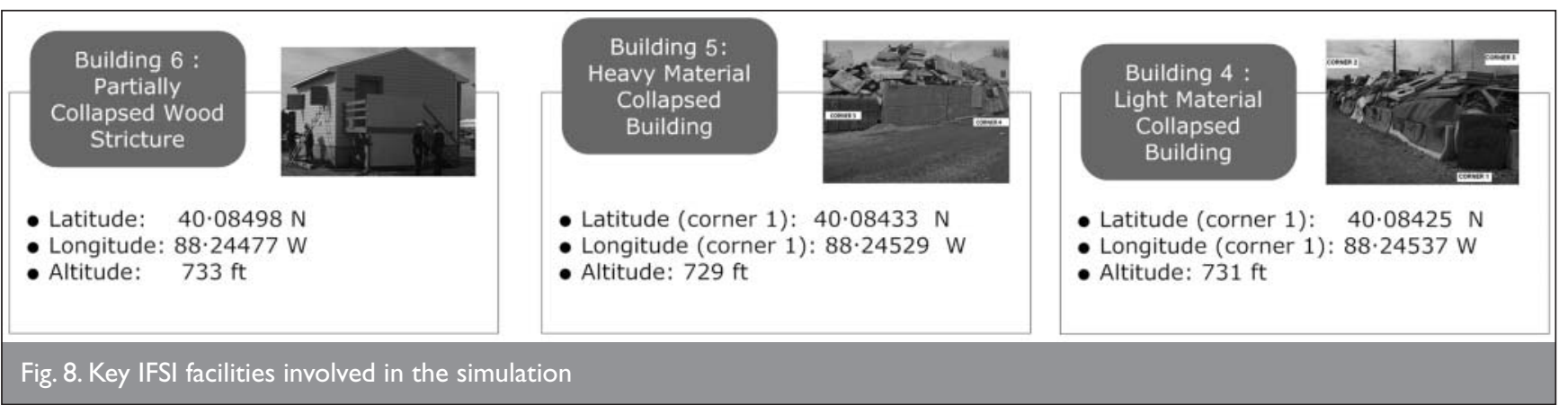

buildings (labelled 4 and 5 respectively) and a partially collapsed wooden home (labelled 6).

In disaster simulation first responders and engineers reach the disaster zone to undertake a structure triage. The objective was to 'help identify, select, and prioritise the building(s) with the highest probability of success with respect to finding and rescuing live victims'. ${ }^{5}$ This section presents results of three aspects of system testing including undertaking initial damage reconnaissance and structure triage operation using a mobility platform, building damage assessment using RFID-based PDA application and GIS-based resource allocation and route optimisation system. After the structural triage, the team efforts focused on three buildings (as shown in Fig. 8). The first round of inspections included rapid assessment to consider the feasibility and likelihood of success for rescue operations.

Figures 9 and 10 illustrate the evaluation exercise and the efficiency gains using a mobility platform. The exercise simulated the preliminary damage assessment reconnaissance operation to develop an initial estimate and evaluation of degree of damage and safety issues involved in disaster response. The chosen terrain was rugged and slippery. Efficiency gains were studied both with and without payload. Addition of a $5.9 \mathrm{~kg}$ payload did not make any substantial difference to operator's efficiency during trials. Both still and video data were captured while riding the mobility platform. Captured image and video (Fig. 11) quality was found to be of an acceptable quality to assist decision makers in the decision-making process.

Building assessment was undertaken using an RFID-based system as discussed in section 5.1 (see Fig. 12). In comparison with traditional paper-based approaches, the RFID-based approach to building assessment was found to be much more efficient and accurate. Further trials were, however, considered important to fine tune the system further. RFID scanning was consistent at short ranges (i.e. less than $2 \mathrm{~m}$ ). However, RFID tag reading and scanning performance over ranges greater than $2 \mathrm{~m}$, with tags mounted on metal structures or collapsed 


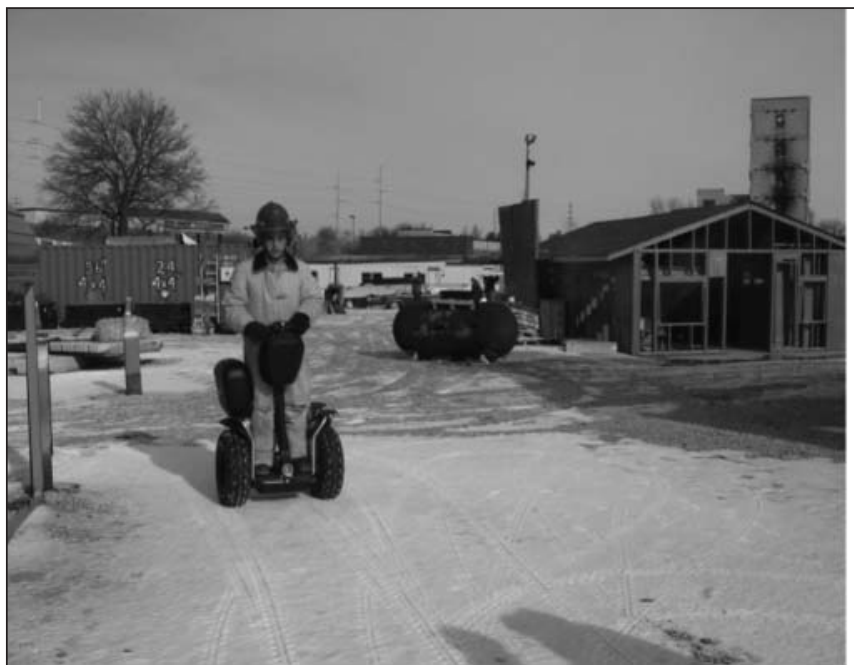

(a)

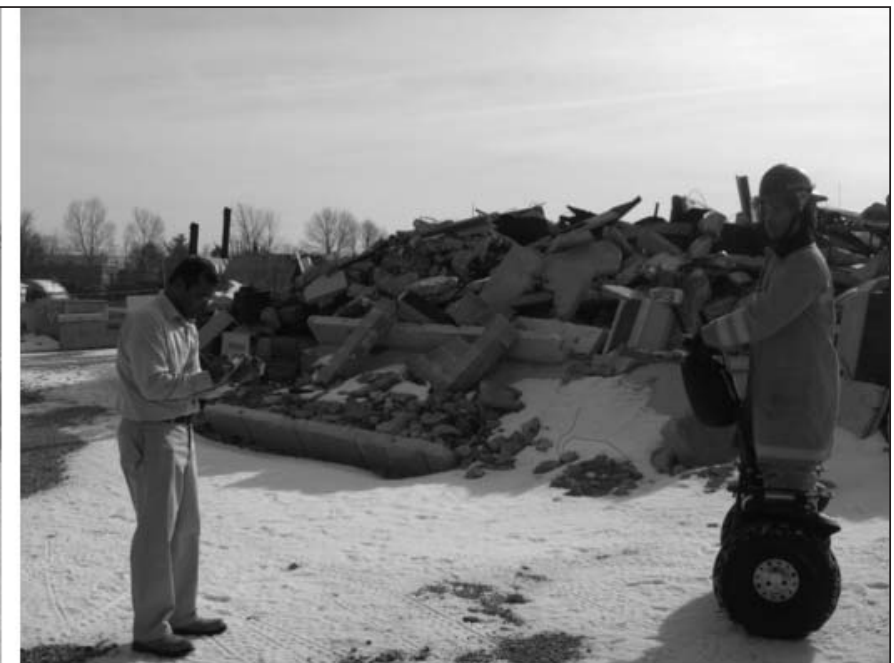

(b)

Fig. 9. Evaluation exercise at IFSI

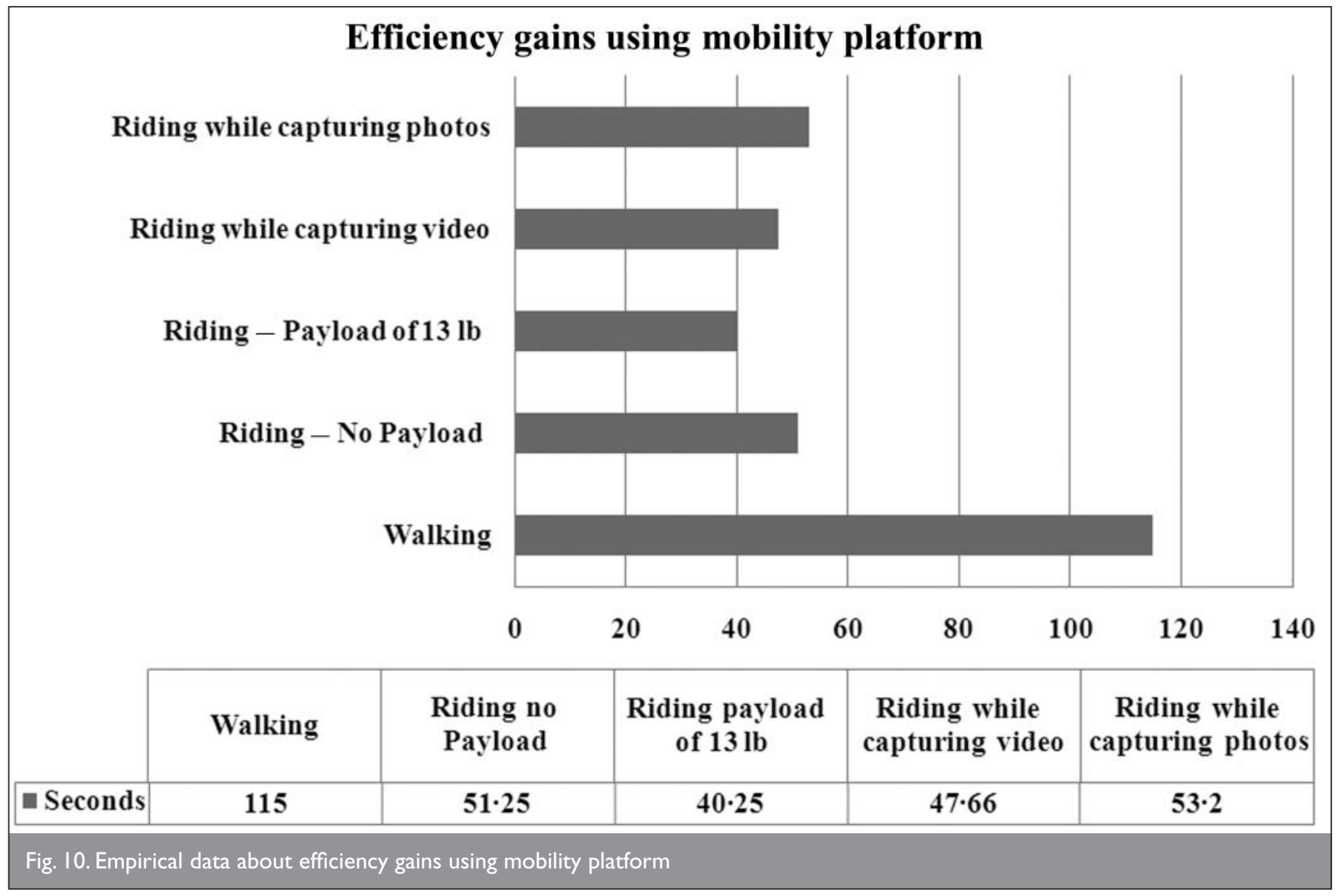

building materials, was observed to be inconsistent. One contributing factor to this was interference caused by heavy metals in the proximity of the RFID tags on the collapsed building site. This highlights the need to use RFID tags that could perform well with metal surfaces and construction materials.

\section{FUTURE WORK AND CONCLUSIONS}

As part of the $\mathrm{CP} 2 \mathrm{R}$ project the present authors are studying, developing and testing tools and methods to support the disaster response process and facilitate planning, strategic decision making and on-demand virtual team formation during disaster response and recovery. This paper has focused 

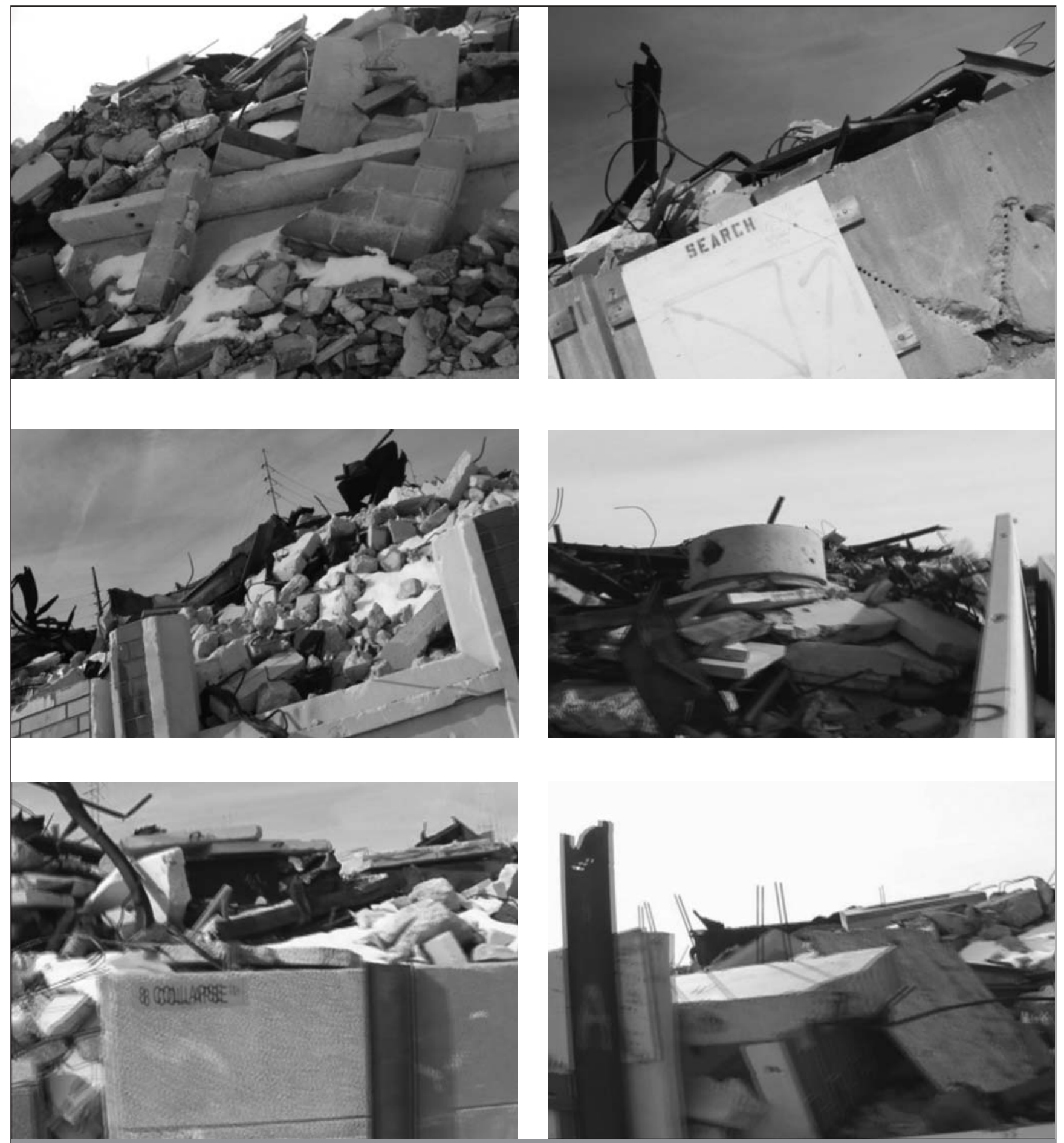

Fig. I I.Video frames and still photographs captured during initial building damage reconnaissance operation undertaken on mobility platform: (a) top — photo capture while riding; (b) lower — video frames captured while riding

primarily on application of emerging technologies to support post-disaster building assessment. An integrated architecture comprising different components including RFID-based structural assessment, personal mobility and information support platform and GIS-based resource optimisation components have also been discussed. System components have been tested in a simulated disaster scenario. It is important to highlight that there is clearly a large gap between academic research and the ability to deploy research products in an actual disaster and/or crisis situation, from the conceptual, methodical, organisational and cultural points of view. Much rigorous testing and broader involvement of stake holders are needed to enable real emergency deployment of the fully integrated CP2R system. Also, keeping in mind the complexity of emergency response operations owing to the interplay of various socio-behavioural-technical systems it is important to seek input from specialists in other fields such as social psychology, organisational science and related fields to understand better the requirements of first responders and other teams responding to disasters. 


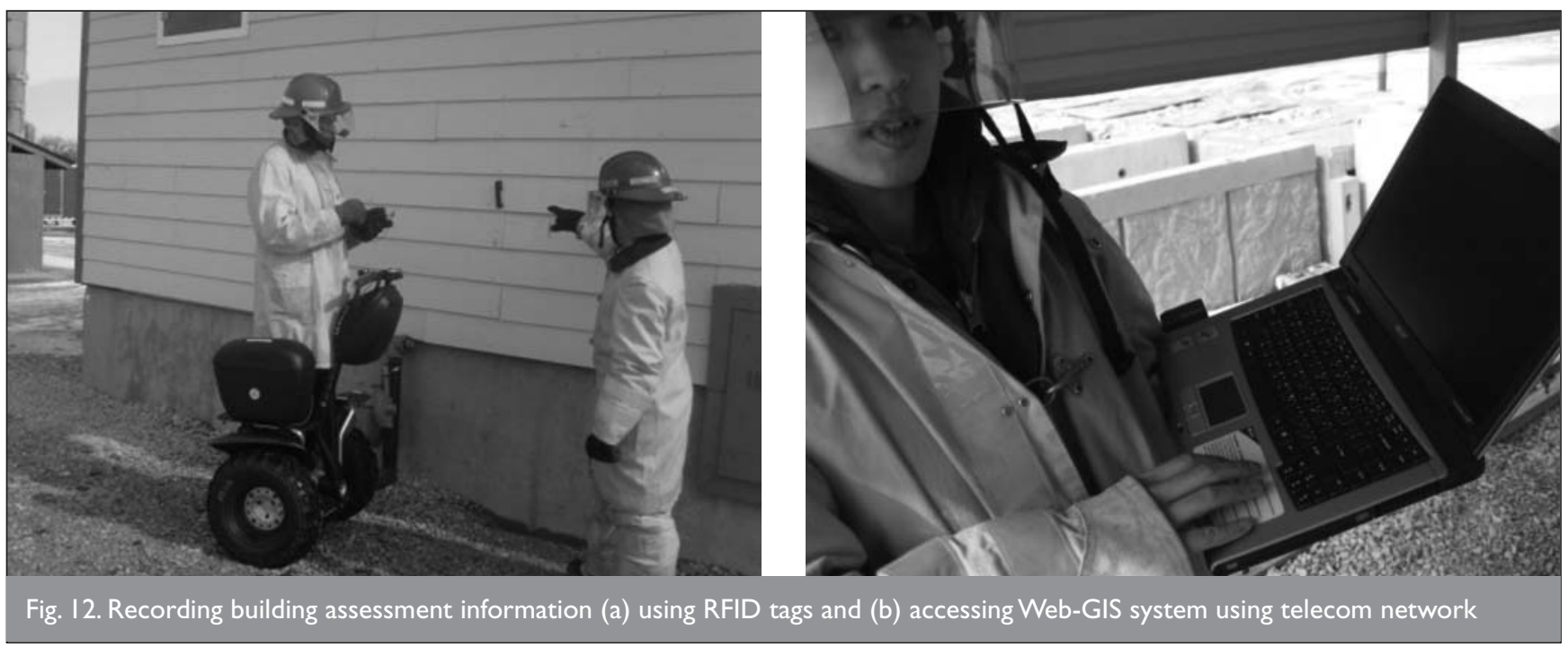

\section{REFERENCES}

1. Hammond D. Engineering the collapse: making the structure safe. Fire Engineering, 1995, 148, No. 11, 49-63.

2. The National Council of Structural Engineers Associations. SEERPlan Manual. Structural Emergency Response Plan. NCSEA, Chicago, Illinois, 2003.

3. w Aldunate R., Peña-Mora F., Nussbaum M. and 0choa S. Robust Mobile Ad Hoc Space for Collaboration to Support Disaster Relief Efforts Involving Critical Physical Infrastructure, Journal of Computing in Civil Engineering, ASCE, Virginia. 2006, 20, No. 1, 13-27.

4. Domel A. World Trade Center Disaster: Structural Engineers At Ground Zero. National Council of Structural Engineers Associations, 2001. See http://www.ncsea.com/ downloads/wtcseerp.pdf for further details (accessed 14 May 2008).

5. Federal Emergency Management Agency. See http://www.fema. gov/pdf/emergency/usr/usr_fog_sept_25_2003_color_final. pdf for further details.

6. Federal Emergency Management Agency USAR Rescue Structures Specialist/US Army Corps Of Engineers. Urban Search and Rescue Structures Specialist Field Operations Guide, 4th edn. US Army Corps of Engineers, 2005.

7. Peña-Mora F., Chen A. Y., Aziz Z., Soibelman L., Liu L. Y., El-Rayes K., Arboleda C. A., Lantz JR T. S., Plans A. P., LAKHERA S and Mathur S. A mobile ad-hoc network enabled collaborative framework supporting civil engineering emergency response. ASCE Journal of Computing in Civil Engineering, 2008 (under review).

8. Federal Emergency Management Agency. Newsphoto. See http://www.photolibrary.fema.gov for further details.

9. International Search and Rescue Response. INSAR: Guidelines. Office for the Coordination of Humanitarian Affairs, INSAR Advisory Group. See http://www.reliefweb.int/undac/ documents/insarag/guidelines/Id-mark.html for further details (last accessed 28 August 2008).

10. International Search and Rescue Advisory Group. See http:// www.reliefweb.int/undac/documents/insarag/guidelines/ topics.html for further details.

11. Voralberg. See http://www.vorarlberg.at/jpg/ kennzeichnungnachinsarag_.jpg for further details.
12. Applied Technology Council. ATC-45 Field Manual: Safety Evaluation of Buildings after Wind Storms and Floods. Applied Technology Council, California. See http://www. atcouncil.org/ATC45.shtml for further details (last accessed 28 August 2008).

13. Structural Engineers Association of New York. World Trade Center Emergency Damage Assessment of Buildings. SEAoNY-Guy Nordenson and Associates, New York, 2003.

14. Applied Technology Council. Users Manual: Mobile PostEarthquake Building Safety Evaluation Data Acquisition System. Applied Technology Council, California, 2003. See http://www.atcouncil.org/pdfs/ATC20i.pdf for further details (last accessed 28 August 2008).

15. Saito K., Spence R. and Foley T. Visual damage assessment using high-resolution satellite images following the 2003 Bam, Iran, earthquake. Earthquake Spectra, 2005, 21, No. S1, S309-S318.

16. Matsuoka M. and YAmAzaki F. Use of satellite SAR intensity imagery for detecting building areas damaged due to earthquakes. Earthquake Spectra, 2004, 20, No. 3, 975-994.

17. Sextos A., Kappos A. J. and Stylianidis K. A. Computer-aided pre and post earthquake assessment of buildings involving database compilation, GIS visualization and mobile data transmission. Computer-aided Civil and Infrastructure Engineering, 2008, 23, No. 1, 59-73.

18. EARTHDATA. See http://www.earthdata.com/p-cbre.html for further details.

19. ReHоR M. Classification of building damages based on laser scanning data. Proceedings of ISPRS Workshop on Laser Scanning and SilviLaser, Espoo, Finland, 12-14 September 2007.

20. Behzadan A. H., Aziz Z., Anumba C. and Kamat V. R. Ubiquitous location tracking for context specific information delivery on construction sites. Automation in Construction, 2008, 17, No. 6, 737-748.

21. Exponent. Wireless Building Monitoring System. 2008. See http://www.exponent.com/practices/techdev/wbms.html for further details (accessed 31/10/2008).

22. International Association of Fire Fighters. Fire Fighters Doing Their Jobs and The Jobs Of Others. See http://www.iaff.org/ Comm/Katrina/Center0903Press.asp for further details. 
23. Fothergill A. Knowledge transfer between researchers and practitioners. Natural Hazards Review, 2000, 1, No. 2, 91-98.

24. National Academic Press. Reducing Disaster Losses Through Better Information. NRC, Washington, DC, 1999.

25. Sawyer S., Tapia A., Pesheck L. and Davenport J. Mobility and the first responder. Communications of the ACM, 2004, 47, No. 3, 62-65.

26. Mansourian A., Rajabifard A., Valadan Zoej M. J and Williamson I. Using SDI and web-based system to facilitate disaster management. COM Computers and Geosciences, 32, No. 3, 303-315.
27. Kamat V. R. and El-Tawil S. Rapid post-disaster evaluation of building damage using augmented situational visualization. Proceedings of Construction Research Congress, American Society of Civil Engineers, Reston, VA, 2005.

28. Wegener S. and Dunagan S. UAV Over-the-Horizon Disaster Management Demonstration Projects, White Paper. NASA Ames Research Center, California, 2000.

29. Tsai M. H., Liu L., Peña-Mora F. and Arboleda C. A preliminary design of disaster-survivable building black-box system for urban disaster response. Sensors in Construction and Infrastructure Management, Special Issue, 2008, 13, 179-192.

\section{What do you think?}

To comment on this paper, please email up to 500 words to the editor at journals@ice.org.uk.Your article will be considered for publication in the journal. The original author(s) will also be invited to respond.

Proceedings journals rely entirely on contributions sent in by urban designers, planners, civil engineers and related professionals, academics and students. Papers should be 2000-5000 words long, with adequate illustrations and references. Please visit www.thomastelford. com/journals for author guidelines and further details. 